Article

\title{
Trends in Smoking Prevalence and Intensity between 2010 and 2018: Implications for Tobacco Control in China
}

\author{
Guoting Zhang ${ }^{1}$, Jiajia Zhan ${ }^{2}$ and Hongqiao Fu ${ }^{1, *}$
}

1 Department of Health Policy and Management, School of Public Health, Peking University Health Science Center, Beijing 100191, China; gtzhang@pku.edu.cn

2 Department of Economics and Public Policy, Business School, Imperial College London, London SW7 2AZ, UK; j.zhan21@imperial.ac.uk

* Correspondence: hofu90@bjmu.edu.cn; Tel.: +86-010-8280-2642

check for

updates

Citation: Zhang, G.; Zhan, J.; Fu, H Trends in Smoking Prevalence and Intensity between 2010 and 2018: Implications for Tobacco Control in China. Int. J. Environ. Res. Public Health 2022, 19, 670. https:// doi.org/10.3390/ijerph19020670

Academic Editors: E

Melinda Mahabee-Gittens and

Ashley L. Merianos

Received: 29 November 2021

Accepted: 6 January 2022

Published: 7 January 2022

Publisher's Note: MDPI stays neutral with regard to jurisdictional claims in published maps and institutional affiliations.

Copyright: (C) 2022 by the authors. Licensee MDPI, Basel, Switzerland. This article is an open access article distributed under the terms and conditions of the Creative Commons Attribution (CC BY) license (https:// creativecommons.org/licenses/by/ $4.0 /)$.
Abstract: Background: China is the world's largest producer and consumer of cigarettes. Since 2010, the Chinese government has implemented many policies to combat the tobacco epidemic, yet little is known about their overall impacts. This study aims to investigate the trends in smoking prevalence and intensity between 2010 and 2018. Methods: We use five waves of data from China Family Panel Studies (CFPS), a nationally representative survey, to examine the trends in smoking prevalence and intensity. We use the chi-square test and $t$-test to examine differences across waves. Binary logistic regressions and linear regressions are applied to examine the association between smoking behaviors and risk factors. Results: The current smoking prevalence dropped from $30.30 \%$ in 2010 (90\% CI 29.47-31.31) to $28.69 \%$ (90\% CI 27.69-29.69) in 2018. As for smoking intensity, the average daily cigarettes consumption decreased steadily from 16.96 cigarettes (90\% CI 16.55-17.36) in 2010 to 15.12 cigarettes $(90 \%$ CI 15.07-15.94) in 2018. Smoking risk factors for men included marriage status, education level, employment status, alcohol consumption, and physical activities. The smoking risk was higher for women with a lower education level, lower household income, unemployment status, and alcohol consumption behavior. Conclusions: Our study shows declined trends in both smoking prevalence and intensity between 2010 and 2018, suggesting some positive progress in tobacco control in China. Nonetheless, to achieve the goal of reducing smoking prevalence among people aged 15 and above to less than $20 \%$ by 2030 , the Chinese government needs to take stronger anti-tobacco measures.

Keywords: smoking prevalence; smoking intensity; tobacco control policies; China

\section{Introduction}

Tobacco control continues to be a top priority in global health promotion. Tobacco use is the leading cause of preventable deaths around the world. It has killed more than five million people every year since 1990, and the corresponding economic burden is rising, especially in low- and middle-income countries [1]. Even though China ratified WHO Framework Convention on Tobacco Control (FCTC) in 2005, the pace of China's tobacco control was slow. In 2010, China was ranked in the bottom $20 \%$ of countries for the implementation of FCTC compliance [2]. Among all countries, China was the largest manufacturer and consumer of cigarettes. Nearly 0.5 trillion cigarettes were produced in China in 1980 and the number rose to 2.38 trillion in 2010, accounting for almost half of global cigarettes production [3,4]. Moreover, only $1 \%$ of cigarettes manufactured in China were exported, with the rest being sold domestically [5]. Consequently, the disease burden associated with tobacco use in China was substantial, both in terms of the direct cost of related disease treatment and the indirect burdens from loss of productivity. According to a World Health Organization report, the direct loss due to treatment of tobacco-attributed 
illnesses reached $¥ 53$ billion, amounting to $1.5 \%$ of China’s total national healthcare expenditures in 2014, and productivity loss due to tobacco-attributed illnesses reached $¥ 297$ billion [6]. Tobacco control was a huge challenge in China's health sector.

Since 2010, the Chinese government has placed a greater emphasis on tobacco control. A significant step was the 12th five-year plan in 2011, in which the Chinese government announced the full implementation of no smoking in public places [7]. Since then, many subnational governments had successively passed new or strengthened existing regulations on smoking in public places. In a striking move, on 28 November 2014, Beijing passed a smoking control ordinance that was strictly in compliance with the FCTC requirements: a ban on smoking in all indoor public and working places, together with the removal of all indoor smoking rooms. In 2015, the Chinese Ministry of Finance increased the tobacco consumption tax on the wholesale price of cigarettes from 5 percent to 11 percent. A specific excise tax of 0.10 RMB (US \$0.017) was also imposed on cigarettes per pack [8]. In 2016, the Chinese government released the Healthy China 2030 plan. It set a clear goal of reducing the prevalence of smoking among people aged 15 and above to less than $20 \%$ by 2030 [9].

A number of studies have investigated the prevalence of smoking in China. However, most of these studies documented the prevalence of smoking only for a certain year or a certain district [10-14]. Some public repositories and organizations have already revealed some descriptive results about China's smoking prevalence, but they mainly focus on the global comparison of tobacco use or just investigate a certain year's situation $[6,15,16]$. Studies on trends in smoking prevalence tended to concentrate on the first ten years of the twenty-first century or earlier periods [17-19]. China's tobacco control progress in the latest ten years has not been well documented. Therefore, our study aims to analyze the trends in smoking prevalence and intensity across China in recent years. This study may contribute to evaluating the effects of tobacco control policies since 2010 and provide some implications for future actions against the tobacco epidemic.

\section{Methods}

\subsection{Data Sources and Study Population}

We used data from China Family Panel Studies (CFPS) to assess the progress of China's tobacco control between 2010 and 2018. The CFPS was a nationally representative longitudinal survey conducted by the Institute of Social Science Survey at Peking University [20]. It was a biennial survey launched in 2010 and had gained approval from the Institutional Review Board of Peking University (Approval IRB00001052-14010).

Up to now, the CFPS had five waves of publicly released datasets, covering the years 2010, 2012, 2014, 2016, and 2018. Each survey covered 25 provinces excluding Hong Kong, Macao, and Taiwan, as well as Xinjiang, Tibet, Qinghai, Inner Mongolia, Ningxia, and Hainan, which represented $94.5 \%$ of the total population in mainland China. The CFPS mainly conducted face-to-face interviews aided by phone interviews. In the 2010 baseline survey, the response rate was $74.9 \%$ and it finally successfully interviewed 14,960 households. In the following surveys, it successfully collected data from 13,453 households, 14,144 households, 14,763 households, and 14,218 households, and the response rates were $79.4 \%, 77.9 \%, 77.12 \%$, and $69.3 \%$, respectively. It collected extensive information on demographic characteristics, socioeconomic status, health-related behaviors and many other respects. We primarily used information about smoking behaviors, demographic characteristics, and some other health behaviors for this study.

We incorporated those aged over 15 in our analysis because the questionnaire for children aged 15 and below did not include any questions on smoking behaviors. We further excluded samples that had missing values on variables presented in Table 1 . As a result, a total of 149,257 observations (33,487 from 2010, 30,688 from 2012, 29,067 from 2014, 29,070 from 2014, 26,945 from 2018) were included for smoking prevalence analysis. Sample sizes by subgroups were also presented (Appendix A Table A1). When we analyzed smoking intensity, we only included samples who were current smokers. Hence, 43,046 observations 
(9905 from 2010, 8957 from 2012, 8239 from 2014, 8125 from 2016, 7820 from 2018) were included for analysis.

Table 1. Trends in smoking prevalence across region, residence, gender, educational level and age groups in China (2010-2018).

\begin{tabular}{|c|c|c|c|c|c|c|c|c|}
\hline $\begin{array}{l}\text { Current } \\
\text { Smoker }\end{array}$ & $\begin{array}{c}2010 \\
\text { Weighted } \\
\text { Proportion } \\
(90 \% \text { CI })\end{array}$ & $\begin{array}{c}2012 \\
\text { Weighted } \\
\text { Proportion } \\
(90 \% \text { CI })\end{array}$ & $\begin{array}{c}2014 \\
\text { Weighted } \\
\text { Proportion } \\
(90 \% \text { CI) }\end{array}$ & $\begin{array}{c}2016 \\
\text { Weighted } \\
\text { Proportion } \\
(90 \% \text { CI })\end{array}$ & $\begin{array}{c}2018 \\
\text { Weighted } \\
\text { Proportion } \\
(90 \% \text { CI })\end{array}$ & 2010-2014 & $\begin{array}{l}\text { Difference } \\
\text { 2014-2018 }\end{array}$ & 2010-2018 \\
\hline Individuals & $\begin{array}{c}30.39 \% \\
(29.47-31.31)\end{array}$ & $\begin{array}{c}28.21 \% \\
(27.34-29.08)\end{array}$ & $\begin{array}{c}27.04 \% \\
(25.94-28.14)\end{array}$ & $\begin{array}{c}26.31 \% \\
(25.38-27.25)\end{array}$ & $\begin{array}{c}28.69 \% \\
(27.69-29.69)\end{array}$ & $-0.033^{* * *}$ & $0.016^{* * *}$ & $-0.017^{* * *}$ \\
\hline \multicolumn{9}{|l|}{ Gender } \\
\hline Female & $\begin{array}{c}3.21 \% \\
(2.50-3.93)\end{array}$ & $\begin{array}{c}2.93 \% \\
(2.34-3.52)\end{array}$ & $\begin{array}{c}2.75 \% \\
(2.16-3.34)\end{array}$ & $\begin{array}{c}3.52 \% \\
(2.78-4.26)\end{array}$ & $\begin{array}{c}3.02 \% \\
(2.39-3.65)\end{array}$ & $-0.005^{* *}$ & 0.003 & -0.002 \\
\hline Male & $\begin{array}{c}56.76 \% \\
(55.33-58.19)\end{array}$ & $\begin{array}{c}55.00 \% \\
(53.52-56.47)\end{array}$ & $\begin{array}{c}51.94 \% \\
(49.98-53.90)\end{array}$ & $\begin{array}{c}48.57 \% \\
(47.07-50.06)\end{array}$ & $\begin{array}{c}53.12 \% \\
(51.44-54.79)\end{array}$ & $-0.048^{* * *}$ & 0.012 & $-0.036^{* * *}$ \\
\hline \multicolumn{9}{|l|}{ Region } \\
\hline Eastern & $\begin{array}{c}28.47 \% \\
(27.28-29.65)\end{array}$ & $\begin{array}{c}27.26 \% \\
(26.05-28.49)\end{array}$ & $\begin{array}{c}24.80 \% \\
(23.45-26.16)\end{array}$ & $\begin{array}{c}25.17 \% \\
(23.75-26.59)\end{array}$ & $\begin{array}{c}26.94 \% \\
(25.56-28.31)\end{array}$ & $-0.037^{* * *}$ & $0.021^{* * *}$ & $-0.015^{* *}$ \\
\hline Central & $\begin{array}{c}30.37 \% \\
(28.94-31.81)\end{array}$ & $\begin{array}{c}28.34 \% \\
(26.70-29.98)\end{array}$ & $\begin{array}{c}27.09 \% \\
(26.12-28.06)\end{array}$ & $\begin{array}{c}26.79 \% \\
(25.24-28.34)\end{array}$ & $\begin{array}{c}28.64 \% \\
(27.20-30.07)\end{array}$ & $-0.033^{* * *}$ & 0.015 * & $-0.017^{*}$ \\
\hline Western & $\begin{array}{c}33.14 \% \\
(31.22-35.06)\end{array}$ & $\begin{array}{c}29.54 \% \\
(27.77-31.32)\end{array}$ & $\begin{array}{c}30.67 \% \\
(28.59-32.75)\end{array}$ & $\begin{array}{c}27.49 \% \\
(25.72-29.25)\end{array}$ & $\begin{array}{c}31.43 \% \\
(29.17-33.69)\end{array}$ & $-0.025^{* *}$ & 0.008 & -0.017 \\
\hline \multicolumn{9}{|l|}{ Residence } \\
\hline Rural & $\begin{array}{c}32.28 \% \\
(30.95-33.61)\end{array}$ & $\begin{array}{c}29.10 \% \\
(27.81-30.38)\end{array}$ & $\begin{array}{c}28.89 \% \\
(27.41-30.37)\end{array}$ & $\begin{array}{c}28.26 \% \\
(26.98-29.55)\end{array}$ & $\begin{array}{c}30.05 \% \\
(28.59-31.51)\end{array}$ & $-0.034^{* * *}$ & 0.012 & $-0.022^{* * *}$ \\
\hline Urban & $\begin{array}{c}28.52 \% \\
(27.40-29.64)\end{array}$ & $\begin{array}{c}27.42 \% \\
(26.37-28.48)\end{array}$ & $\begin{array}{c}25.80 \% \\
(24.54-27.06)\end{array}$ & $\begin{array}{c}25.04 \% \\
(23.96-26.13)\end{array}$ & $\begin{array}{c}27.81 \% \\
(26.75-28.87)\end{array}$ & $-0.027^{* * *}$ & $0.020 * * *$ & -0.007 \\
\hline \multicolumn{9}{|l|}{ Education } \\
\hline $\begin{array}{l}\text { Primary or } \\
\text { below }\end{array}$ & $\begin{array}{c}30.48 \% \\
(29.10-31.87)\end{array}$ & $\begin{array}{c}27.93 \% \\
(26.72-29.14)\end{array}$ & $\begin{array}{c}27.44 \% \\
(26.00-28.88)\end{array}$ & $\begin{array}{c}26.43 \% \\
(25.15-27.71)\end{array}$ & $\begin{array}{c}27.90 \% \\
(26.36-29.44)\end{array}$ & $-0.030 * * *$ & 0.005 & $-0.026^{* * *}$ \\
\hline $\begin{array}{l}\text { Secondary or } \\
\text { high school }\end{array}$ & $\begin{array}{c}31.09 \% \\
(30.13-32.05)\end{array}$ & $\begin{array}{c}29.62 \% \\
(28.59-30.65)\end{array}$ & $\begin{array}{c}27.68 \% \\
(26.54-28.82)\end{array}$ & $\begin{array}{c}27.53 \% \\
(26.43-28.63)\end{array}$ & $\begin{array}{c}31.54 \% \\
(30.54-32.55)\end{array}$ & $-0.034^{* * *}$ & $0.039^{* * *}$ & 0.005 \\
\hline $\begin{array}{l}\text { College or } \\
\text { above } \\
\text { Age vears }\end{array}$ & $\begin{array}{c}25.67 \% \\
(23.59-27.75)\end{array}$ & $\begin{array}{c}22.82 \% \\
(20.72-24.93)\end{array}$ & $\begin{array}{c}22.19 \% \\
(19.87-24.52)\end{array}$ & $\begin{array}{c}19.02 \% \\
(16.91-21.13)\end{array}$ & $\begin{array}{c}21.44 \% \\
(19.40-23.49)\end{array}$ & $-0.035^{* *}$ & -0.008 & $-0.042 * *$ \\
\hline 16-29 & $\begin{array}{c}22.96 \% \\
(21.46-24.47)\end{array}$ & $\begin{array}{c}20.05 \% \\
(18.71-21.40)\end{array}$ & $\begin{array}{c}19.74 \% \\
(18.30-21.19)\end{array}$ & $\begin{array}{c}17.20 \% \\
(15.93-18.47)\end{array}$ & $\begin{array}{c}22.22 \% \\
(20.61-23.84)\end{array}$ & $-0.032 * * *$ & $0.025^{* *}$ & -0.007 \\
\hline 30-39 & $\begin{array}{c}32.66 \% \\
(31.22-34.10)\end{array}$ & $\begin{array}{c}30.44 \% \\
(28.83-32.05)\end{array}$ & $\begin{array}{c}27.91 \% \\
(26.09-29.74)\end{array}$ & $\begin{array}{c}29.71 \% \\
(27.99-31.43)\end{array}$ & $\begin{array}{c}31.71 \% \\
(29.77-33.64)\end{array}$ & $-0.048^{* * *}$ & $0.038^{* * *}$ & -0.01 \\
\hline $40-49$ & $\begin{array}{c}34.85 \% \\
(33.48-36.22)\end{array}$ & $\begin{array}{c}32.14 \% \\
(30.75-33.52)\end{array}$ & $\begin{array}{c}30.76 \% \\
(29.12-32.41)\end{array}$ & $\begin{array}{c}29.70 \% \\
(28.09-31.31)\end{array}$ & $\begin{array}{c}30.17 \% \\
(28.50-31.84)\end{array}$ & $-0.041^{* * *}$ & -0.006 & $-0.047^{* * *}$ \\
\hline $50-59$ & $\begin{array}{c}35.65 \% \\
(34.27-37.03)\end{array}$ & $\begin{array}{c}33.92 \% \\
(32.49-35.35)\end{array}$ & $\begin{array}{c}31.46 \% \\
(29.69-33.23)\end{array}$ & $\begin{array}{c}30.67 \% \\
(28.92-32.43)\end{array}$ & $\begin{array}{c}32.15 \% \\
(30.33-33.97)\end{array}$ & $-0.042 * * *$ & 0.007 & $-0.035^{* * *}$ \\
\hline $60-69$ & $\begin{array}{c}31.73 \% \\
(30.09-33.37)\end{array}$ & $\begin{array}{c}29.70 \% \\
(28.23-31.17)\end{array}$ & $\begin{array}{c}28.56 \% \\
(26.86-30.26)\end{array}$ & $\begin{array}{c}29.11 \% \\
(27.34-30.87)\end{array}$ & $\begin{array}{c}29.88 \% \\
(28.38-31.38)\end{array}$ & $-0.032^{* *}$ & 0.013 & -0.019 \\
\hline$\geq 70$ & $\begin{array}{c}26.00 \% \\
(23.52-28.48)\end{array}$ & $\begin{array}{c}23.61 \% \\
(21.15-26.07)\end{array}$ & $\begin{array}{c}23.46 \% \\
(20.85-26.06)\end{array}$ & $\begin{array}{c}22.19 \% \\
(19.77-24.60)\end{array}$ & $\begin{array}{c}24.21 \% \\
(22.19-26.22)\end{array}$ & -0.025 & 0.007 & -0.018 \\
\hline
\end{tabular}

Note: Weighted percentages and $90 \%$ confidence intervals were reported in the table. Chi-square test was used to compare the change in proportions. ${ }^{* * *},{ }^{* *}$ and ${ }^{*}$ denoted statistical significance at the $1 \%, 5 \%$, and $10 \%$ level, respectively.

\subsection{Indicators}

The primary variables of interest in this study were self-reported smoking status and daily cigarette consumption. The variable current smoker was assessed by the following question: "Did you smoke cigarettes in the past month?". Those who smoked cigarettes in the past month were assigned a value of 1 ; otherwise, it equaled 0 . We used the average number of cigarettes smoked per day to measure smoking intensity. This variable was assessed using the question, "How many cigarettes do you smoke on average per day?". Non-smokers did not need to answer this question. These questions remained unchanged across waves. The previous studies used the information from the CFPS to analyze smoking behaviors in China [21-23].

To identify the risk factors of smoking prevalence and intensity, two sets of explanatory variables were used. The first set were sociodemographic variables. We included age, 
square of age, gender (female, male), education (primary school or below, secondary or high school, college or above), marital status (unmarried, married or cohabited, divorced or widowed), employment status (unemployed, self-employed, employed by others), region (eastern, central, western), rural/urban status, and household income (lower than average, equal to or higher than average). The second set of explanatory variables were those that measure health behaviors. Current drinkers were defined as those who drank more than three times a week. People who did physical activities referred to those who did exercise at least once a week.

\subsection{Statistical Analysis}

We conducted a descriptive analysis to examine the trends in smoking prevalence and intensity between 2010 and 2018. Given that the CFPS was a longitudinal survey and it oversampled in five "large provinces" (they are Shanghai, Liaoning, Henan, Gansu, and Guangdong), we conducted statistical analyses using the cross-sectional weights for each wave to ensure that our results were nationally representative [20]. We presented variable means with $90 \%$ confidence intervals (CIs) and used the chi-square test and $t$-test to examine the differences in results between survey years.

Given substantial differences in social and economic development across different strata, we examined smoking prevalence and intensity by geographic regions and urban/rural status. We separated samples by education level and by gender to test the education gradient and gender differences in smoking behaviors. Age-specific (16-29, 30-39,

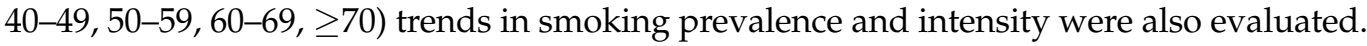

We used binary logistic regression to investigate factors associated with current smoking behaviors using pooled data from five waves. Results were presented as odds ratios (ORs) with $90 \%$ CIs. The modified Poisson regression was also used as a supplement for its easier interpretation of results, which were presented as risk ratios (RRs) with $90 \%$ CIs. Linear regression models were used to assess the associations between the average number of daily cigarettes consumption and the risk factors. Results were presented as coefficients with $90 \%$ CIs. We included two sets of explanatory variables in the regression analysis. The first set were sociodemographic variables, and the second set were variables about individual health behaviors. Definitions of these variables were described in the previous subsection. In addition, we added dummies of the survey years and geographic regions to control time and district fixed effects. Due to the large gender differences in smoking prevalence and smoking intensity, the regression models were gender stratified. All statistical analyses were conducted in Stata SE 15.0.

\section{Results}

\subsection{Smoking Prevalence}

Table 1 shows the trends of smoking prevalence between 2010 and 2018. The overall smoking prevalence decreased steadily from 30.39\% (90\% CI 29.47-31.31) in 2010 to $26.31 \%$ (90\% CI 25.38-27.25) in 2016 and then increased slightly to $28.69 \%$ (90\% CI 27.69-29.69) in 2018. Smoking was much more prevalent in men than in women. Specifically, in 2010, $56.76 \%$ (90\% CI 55.33-58.19) of men in China were smokers. This proportion was much higher than that for women $(3.21 \%, 90 \%$ CI 2.50-3.93). The large gender difference remained unchanged across survey years (55.00\% in 2012, 51.94\% in 2014, 48.57\% in 2016 and $53.12 \%$ in 2018 vs. $2.93 \%$ in in $2012,2.75 \%$ in $2014,3.52 \%$ in 2016 and $3.02 \%$ in 2018 ), as shown in Table 1. During this period, the smoking prevalence for men decreased significantly by 3.6 percentage points (pp) between 2010 and 2018, while among women, the decrease was not statistically significant.

We found statistically significant regional differences in smoking prevalence. In 2010, the weighted prevalence of smoking in the western region was 33.14\% (90\% CI 31.22-35.06), followed by a prevalence of $30.37 \%$ (90\% CI $28.94-31.81)$ in the central region and $28.47 \%$ (90\% CI 27.28-29.65) in the eastern region. In 2018, this regional pattern remained unchanged and the smoking prevalence in the western region kept at the highest level across 
the three regions. The smoking prevalence decreased significantly by $1.5 \mathrm{pp}$ in the eastern region and 1.7 pp in the central region between 2010 and 2018.

The smoking prevalence by urban/rural status is also shown in Table 1. Between 2010 and 2018, rural residents' smoking prevalence was consistently higher than that of urban residents, though, for both groups, the share of current smokers declined. The prevalence for urban residents decreased from $28.52 \%$ (90\% CI 27.40-29.64) in 2010 to $27.81 \%$ (90\% CI 26.75-28.87) in 2018, and the prevalence for rural residents declined from $32.28 \%$ (90\% CI $30.95-33.61)$ in 2010 to $30.05 \%$ (90\% CI 28.59-31.51) in 2018. It indicates that rural residents aged 16 and above experienced a greater decrease in smoking prevalence than that of urban residents. The gap in smoking prevalence between urban and rural residents had narrowed from 2010 to 2018.

Smoking prevalence varied significantly among people with different educational levels. People with a college degree or above had a much lower smoking prevalence compared with those with secondary or high school education and below. Additionally, smoking prevalence in people with a college degree or above experienced the greatest reduction from 2010 to 2018 . People with primary education or below also had a decline of $2.6 \mathrm{pp}$ in smoking prevalence between 2010 and 2018. As for people with secondary or high school education, the prevalence remained unchanged from 2010 to 2018.

We also examined smoking prevalence by age group. The relationship between smoking prevalence and age was not linear. Take the wave of 2010 as an example. The smoking prevalence was 22.69\% (90\% CI 21.46-24.47) among people aged 16-29 and reached 35.65\% (90\% CI 34.27-37.03) among people aged 50-59. For people aged 60-69 and the group aged over 70, their shares of current smokers were 31.73\% (90\% CI 30.09-33.37) and $26.00 \%$ (90\% CI 23.52-28.48), respectively. There was a similar age pattern in other waves, with the highest smoking prevalence among people aged 50-59. Moreover, between 2010 and 2018, smoking rates for people aged 40-49 and aged 50-59 decreased by 4.7 pp and $3.5 \mathrm{pp}$, respectively. Other age groups also saw a decrease in prevalence over time, but the changes were not statistically significant. Figure 1 provides a more detailed age-specific analysis of smoking prevalence. We can observe inverted U curves of smoking prevalence by age among men respondents. There was a sharp increase from $11.72 \%$ in the population aged 16-20 to $27.28 \%$ in the population aged 21-25 in 2010, suggesting that many people started smoking at a young age. Additionally, we find that smoking prevalence among people aged 16-20 increased from $11.72 \%$ in 2010 to $14.29 \%$ in 2018 . A different pattern of age-specific prevalence was shown for women. Despite the fact that the curves of smoking prevalence in women showed a slight upward trend as age increased, the proportion of women who smoked remained at a low level over the period.

Table 2 shows the results of gender-stratified binary logistic regression on smoking behavior using pooled data from waves of 2010, 2012, 2014, 2016, and 2018, in which the odds ratios and $90 \%$ CIs for each regression are reported. We found risk factors for smoking behavior differed by gender. For men, those who were married or divorced had a much higher smoking prevalence compared with unmarried men (married or cohabited: $\mathrm{OR}=1.430 ; p<0.01$; divorced or widowed: $\mathrm{OR}=1.943, p<0.01$ ). Men with higher education were less likely to be smokers (secondary or high school: $\mathrm{OR}=0.822, p<0.01$; college or above: $\mathrm{OR}=0.512, p<0.01)$. Being employed increased the odds of being a smoker (self-employed: $\mathrm{OR}=1.381, p<0.01$; employed by others: $\mathrm{OR}=1.654, p<0.01$ ). The association between smoking prevalence and the level of household income was positive (equal to or higher than average: $\mathrm{OR}=1.033, p<0.1$ ). Current drinking behavior was positively associated with smoking behavior $(\mathrm{OR}=1.835, p<0.01)$. Doing physical activities decreased the possibility of smoking $(\mathrm{OR}=0.796, p<0.01)$. 


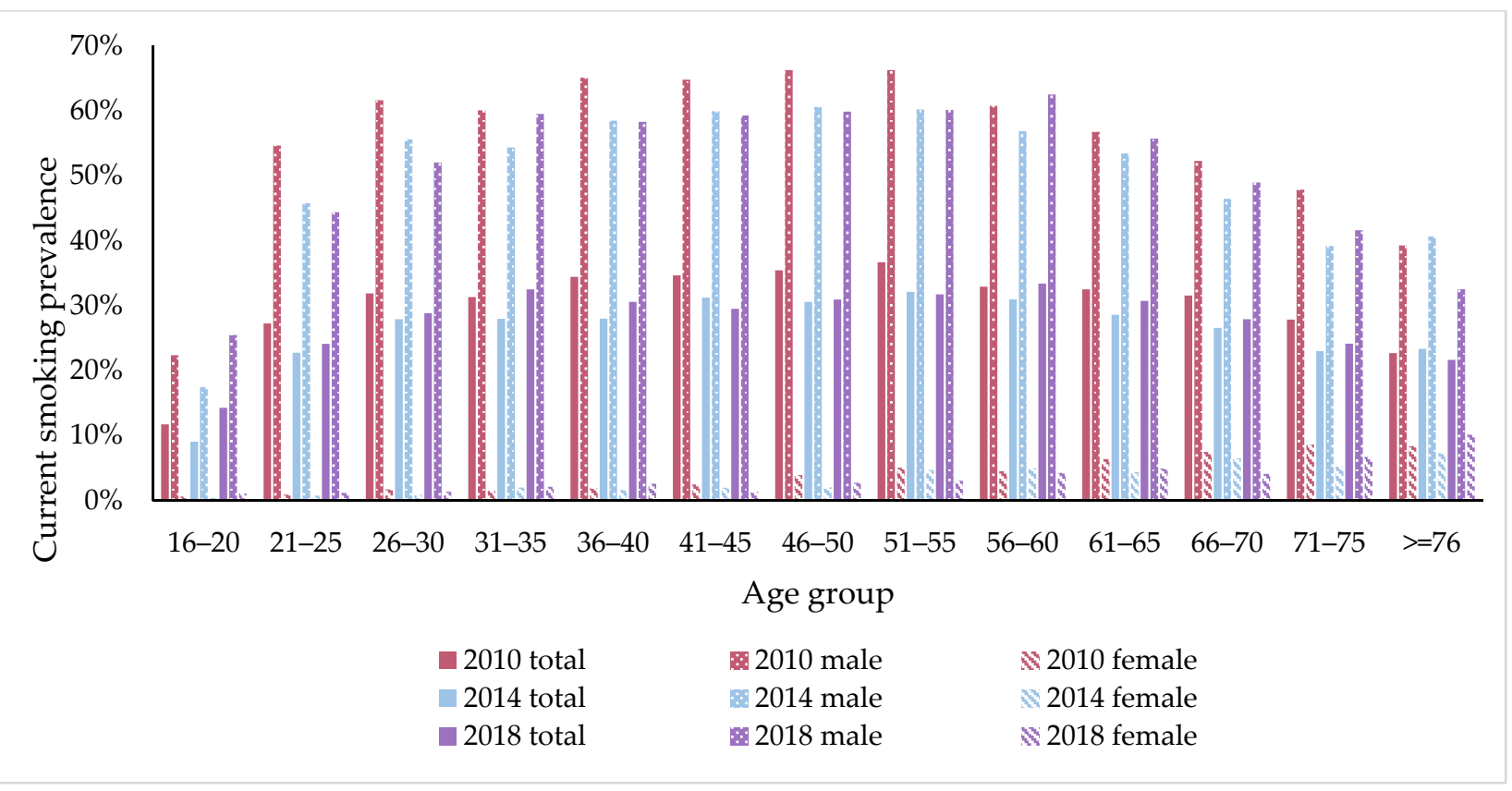

Figure 1. Age-specific prevalence of smoking prevalence in China in 2010, 2014 and 2018. Data source: China Family Panel Studies.

For women, unlike men, those who were married were less likely to be smokers (married or cohabited: $\mathrm{OR}=0.602, p<0.01$ ). In addition, employment status and smoking behavior were associated in different ways for women. Women with jobs were less likely to smoke (self-employed: $\mathrm{OR}=0.847, p<0.01$; employed by others: $\mathrm{OR}=0.749, p<0.01$ ). Women with a higher level of household income had lower smoking prevalence (equal to or higher than average: $\mathrm{OR}=0.659, p<0.01$ ). Similar to that of men, a lower level of education, lower level of household income, and current drinking behavior increased the odds of being a smoker among women.

We also used modified Poisson regression to estimate the risk ratios because results interpretation was easier (Appendix A Table A2). There were small differences between results from the two methods and the findings remained unchanged. For men, the risk of smoking was increased by $21.9 \%$ among those who were married or cohabited relative to the unmarried men (married or cohabited: $R R=1.219 ; p<0.01$ ). The divorced or widowed men had a $37.5 \%$ increase in risk of being current smokers, compared to the unmarried men (divorced or widowed: $\mathrm{RR}=1.375, p<0.01$ ). Current smoking behavior was 1.169 times more likely to occur among self-employed people than among the unemployed (self-employed: $R R=1.169, p<0.01$ ). People who were employed by others had a $26.2 \%$ increase in risk of being current smokers compared to the unemployed (employed by others: $R R=1.262, p<0.01)$. Current drinkers had 1.255 times the risk of smoking compared to non-drinkers $(R R=1.255, p<0.01)$. For women, the risk of smoking among the married or cohabited was reduced by $38.8 \%$ relative to the unmarried (married or cohabited: $R R=0.612, p<0.01$ ). Compared to the employed, the women who were self-employed and employed by others had a $14.5 \%$ and $24.1 \%$ reduction in risk of being current smokers, respectively (self-employed: $R R=0.855, p<0.01$; employed by others: $\mathrm{RR}=0.759, p<0.01$ ). The risk of smoking was $32.6 \%$ less among women with a higher level of household income compared with women with a lower level of household income $(\mathrm{RR}=0.674, p<0.01)$. 
Table 2. Risk factors associated with current smoking status.

\begin{tabular}{|c|c|c|c|}
\hline & Total & Women & Men \\
\hline Current Smoking & $\begin{array}{c}\text { Odds Ratio } \\
(90 \% \text { CI })\end{array}$ & $\begin{array}{l}\text { Odds Ratio } \\
(90 \% \mathrm{CI})\end{array}$ & $\begin{array}{c}\text { Odds Ratio } \\
\text { (90\% CI) }\end{array}$ \\
\hline \multicolumn{4}{|l|}{ Marital status } \\
\hline Unmarried & 1(ref) & 1(ref) & 1(ref) \\
\hline \multirow[t]{2}{*}{ Married or cohabited } & $0.746^{* * *}$ & $0.602 * * *$ & $1.431^{* * *}$ \\
\hline & $(0.714 \sim 0.779)$ & $(0.475 \sim 0.764)$ & $(1.360 \sim 1.505)$ \\
\hline Divorced or widowed & $\begin{array}{c}0.697^{* * *} \\
(0.657 \sim 0.739)\end{array}$ & $\begin{array}{c}0.796 \\
(0.618 \sim 1.026)\end{array}$ & $\begin{array}{c}1.943^{* * *} \\
(1.802 \sim 2.096)\end{array}$ \\
\hline \multicolumn{4}{|l|}{ Educational level } \\
\hline Primary or below & 1(ref) & 1(ref) & 1(ref) \\
\hline \multirow[t]{2}{*}{ Secondary or high school } & $1.248^{* * *}$ & $0.720^{* * *}$ & $0.822^{* * *}$ \\
\hline & $(1.218 \sim 1.278)$ & $(0.656 \sim 0.790)$ & $(0.798 \sim 0.847)$ \\
\hline \multirow[t]{2}{*}{ College or above } & $0.809 * * *$ & $0.523^{* * *}$ & $0.512^{* * *}$ \\
\hline & $(0.774 \sim 0.846)$ & $(0.413 \sim 0.663)$ & $(0.486 \sim 0.540)$ \\
\hline \multicolumn{4}{|l|}{ Household income } \\
\hline Lower than average & 1(ref) & 1(ref) & 1(ref) \\
\hline \multirow[t]{2}{*}{ Equal to or higher than average } & $0.909 * * *$ & $0.659 * * *$ & $1.033^{*}$ \\
\hline & $(0.889 \sim 0.930)$ & $(0.606 \sim 0.716)$ & $(1.004 \sim 1.064)$ \\
\hline \multicolumn{4}{|l|}{ Work type } \\
\hline Unemployed & 1(ref) & 1(ref) & 1(ref) \\
\hline \multirow[t]{2}{*}{ Self employed } & $1.694^{* * *}$ & $0.847^{* * *}$ & $1.381^{* * *}$ \\
\hline & $(1.646 \sim 1.744)$ & $(0.774 \sim 0.927)$ & $(1.330 \sim 1.435)$ \\
\hline \multirow[t]{2}{*}{ Employed by others } & $2.517^{* * *}$ & $0.749^{* * *}$ & $1.654^{* * *}$ \\
\hline & $(2.440 \sim 2.597)$ & $(0.660 \sim 0.852)$ & $(1.590-1.722)$ \\
\hline \multicolumn{4}{|l|}{ Current drinker } \\
\hline No & 1(ref) & 1(ref) & 1(ref) \\
\hline \multirow[t]{2}{*}{ Yes } & $5.141^{* * *}$ & $3.997 * * *$ & $1.835^{* * *}$ \\
\hline & $(5.009 \sim 5.276)$ & (3.551 4.499) & $(1.780 \sim 1.890)$ \\
\hline \multicolumn{4}{|l|}{ Physical activity } \\
\hline No & 1(ref) & 1(ref) & 1(ref) \\
\hline \multirow[t]{2}{*}{ Yes } & $0.922 * * *$ & 0.954 & $0.796^{* * *}$ \\
\hline & $(0.902 \sim 0.943)$ & $(0.883 \sim 1.030)$ & $(0.774 \sim 0.818)$ \\
\hline Observations & 146,694 & 74,457 & 72,237 \\
\hline
\end{tabular}

Note: In columns 2 and 3, binary logistic regression models were adjusted for geographical regions, urban/rural status, age and age square, and wave dummies using the pooled data from waves of 2010, 2012, 2014, 2016, and 2018. In column 1 , the binary logistic regression model further included the gender variable in addition to other control variables. $90 \%$ Confidence intervals for Odds Ratio were reported in the brackets. ${ }^{* * *} p<0.01,{ }^{*} p<0.1$.

\subsection{Smoking Intensity}

Table 3 presents trends in smoking intensity among current smokers between 2010 and 2018. Among current smokers, the average number of daily cigarettes smoked decreased from 16.96 (90\% CI 16.55-17.36) in 2010 to 15.12 (90\% CI 15.07-15.94) in 2018, suggesting that current smokers had consumed fewer cigarettes over time.

There was also a gender gap on the average number of daily cigarettes smoked. In each wave, men smokers consumed more cigarettes than women smokers. During the 2010-2018 period, the average daily cigarettes consumed by men smokers decreased by 1.90 , while the average daily cigarettes consumed by women smokers remained largely unchanged. As for trends across regions, the western region had the highest number of average daily cigarettes in the beginning, but then it kept at the lowest level from 2012 to 2018. In other words, the western regions experienced the greatest reduction of average daily cigarettes between 2010 and 2018. The eastern and central regions also displayed decreasing trends in smoking intensity among current smokers. The average daily cigarettes smoked for urban and rural smokers reduced from 16.31 (90\% CI 15.85-16.78) and 17.54 (90\% CI 16.98-18.08) in 2010 to 15.04 (90\% CI 14.60-15.49) and 15.23 (90\% CI 14.72-15.73) in 2018, respectively. Throughout the years, the smoking intensity gap between urban and rural smokers had narrowed. 
Table 3. The weighted number of average daily cigarettes smoked among current smokers in China (2010-2018).

\begin{tabular}{|c|c|c|c|c|c|c|c|c|}
\hline \multirow{2}{*}{$\begin{array}{l}\text { Number of } \\
\text { Average Daily } \\
\text { Cigarettes }\end{array}$} & 2010 & 2012 & 2014 & 2016 & 2018 & \multicolumn{3}{|c|}{ Difference } \\
\hline & $\begin{array}{l}\text { Weighted } \\
\text { Means } \\
(90 \% \text { CI })\end{array}$ & $\begin{array}{l}\text { Weighted } \\
\text { Means } \\
(90 \% \text { CI })\end{array}$ & $\begin{array}{l}\text { Weighted } \\
\text { Means } \\
(90 \% \text { CI })\end{array}$ & $\begin{array}{l}\text { Weighted } \\
\text { Means } \\
(90 \% \text { CI })\end{array}$ & $\begin{array}{l}\text { Weighted } \\
\text { Means } \\
(90 \% \text { CI })\end{array}$ & 2010-2014 & 2014-2018 & 2010-2018 \\
\hline Individuals & $\begin{array}{c}16.96 \\
(16.55-17.36)\end{array}$ & $\begin{array}{c}16.19 \\
(15.78-16.60)\end{array}$ & $\begin{array}{c}15.83 \\
(15.42-16.24)\end{array}$ & $\begin{array}{c}15.50 \\
(15.07-15.94)\end{array}$ & $\begin{array}{c}15.12 \\
(14.76-15.48)\end{array}$ & $-1.125 * * *$ & $-0.710^{* * *}$ & $-1.836^{* * *}$ \\
\hline \multicolumn{9}{|l|}{ Gender } \\
\hline Female & $\begin{array}{c}12.14 \\
(11.27-13.01)\end{array}$ & $\begin{array}{c}13.03 \\
(12.09-13.96)\end{array}$ & $\begin{array}{c}12.12 \\
(10.97-13.28)\end{array}$ & $\begin{array}{c}10.95 \\
(9.86-12.04)\end{array}$ & $\begin{array}{c}11.27 \\
(10.20-12.34)\end{array}$ & -0.013 & -0.855 & -0.869 \\
\hline Male & $\begin{array}{c}17.21 \\
(16.81-17.63)\end{array}$ & $\begin{array}{c}16.37 \\
(15.96-16.78)\end{array}$ & $\begin{array}{c}16.03 \\
(15.62-16.44)\end{array}$ & $\begin{array}{c}15.83 \\
(15.39-16.26)\end{array}$ & $\begin{array}{c}15.33 \\
(14.96-15.69)\end{array}$ & $-1.187^{* * *}$ & $-0.705^{* * *}$ & $-1.892^{* * *}$ \\
\hline Region & & - & & & & & & \\
\hline East & $\begin{array}{c}16.74 \\
(16.02-17.45)\end{array}$ & $\begin{array}{c}16.39 \\
(16.05-16.74)\end{array}$ & $\begin{array}{c}16.09 \\
(15.49-16.69)\end{array}$ & $\begin{array}{c}15.97 \\
(15.35-16.59)\end{array}$ & $\begin{array}{c}15.36 \\
(14.78-15.95)\end{array}$ & $-0.652 *$ & $-0.722 * *$ & $-1.374^{* * *}$ \\
\hline Central & $\begin{array}{c}16.93 \\
(16.25-17.60)\end{array}$ & $\begin{array}{c}16.61 \\
(15.90-17.32)\end{array}$ & $\begin{array}{c}16.37(15.71- \\
17.03)\end{array}$ & $\begin{array}{c}16.00 \\
(15.54-16.47)\end{array}$ & $\begin{array}{c}15.53 \\
(15.06-15.99)\end{array}$ & -0.555 & $-0.845^{* *}$ & $-1.401^{* * *}$ \\
\hline West & $\begin{array}{c}17.26 \\
(16.53-17.98)\end{array}$ & $\begin{array}{c}15.37 \\
(14.45-16.28)\end{array}$ & $\begin{array}{c}14.86 \\
(14.00-15.71)\end{array}$ & $\begin{array}{c}14.21 \\
(13.71-14.71)\end{array}$ & $\begin{array}{c}14.35 \\
(13.73-14.97)\end{array}$ & $-2.398^{* * *}$ & -0.508 & $-2.906^{* * *}$ \\
\hline \multicolumn{9}{|l|}{ Residence } \\
\hline Rural & $\begin{array}{c}17.54 \\
(16.98-18.08)\end{array}$ & $\begin{array}{c}16.92 \\
(16.34-17.49)\end{array}$ & $\begin{array}{c}16.10 \\
(15.53-16.66)\end{array}$ & $\begin{array}{c}15.67 \\
(15.18-16.17)\end{array}$ & $\begin{array}{c}15.23 \\
(14.72-15.73)\end{array}$ & $-1.441^{* * *}$ & $-0.869 * * *$ & $-2.310^{* * *}$ \\
\hline Urban & $\begin{array}{c}16.31 \\
(15.85-16.78)\end{array}$ & $\begin{array}{c}15.50 \\
(15.07-15.93)\end{array}$ & $\begin{array}{c}15.63 \\
(15.15-16.11)\end{array}$ & $\begin{array}{c}15.38 \\
(14.79-15.96)\end{array}$ & $\begin{array}{c}15.04 \\
(14.60-15.49)\end{array}$ & $-0.681 *$ & $-0.586^{*}$ & $-1.267^{* * *}$ \\
\hline \multicolumn{9}{|l|}{ Education } \\
\hline Primary or below & $\begin{array}{c}17.52 \\
(16.99-18.06)\end{array}$ & $\begin{array}{c}17.12 \\
(16.50-17.74)\end{array}$ & $\begin{array}{c}16.58 \\
(15.98-17.18)\end{array}$ & $\begin{array}{c}16.15 \\
(15.47-16.82)\end{array}$ & $\begin{array}{c}16.46 \\
(15.82-17.10)\end{array}$ & $-0.945^{* *}$ & -0.121 & $-1.066^{* * *}$ \\
\hline $\begin{array}{l}\text { Secondary or high } \\
\text { school }\end{array}$ & $\begin{array}{c}16.84 \\
(16.28-17.40)\end{array}$ & $\begin{array}{c}15.68 \\
(15.22-16.13)\end{array}$ & $\begin{array}{c}15.78 \\
(15.31-16.24)\end{array}$ & $\begin{array}{c}15.22 \\
(14.76-15.69)\end{array}$ & $\begin{array}{c}14.79 \\
(14.37-15.22)\end{array}$ & $-1.062^{* * *}$ & $-0.986^{* * *}$ & $-2.048^{* * *}$ \\
\hline College or above & $\begin{array}{c}13.92 \\
(13.05-14.78)\end{array}$ & $\begin{array}{c}13.80 \\
(12.95-14.64)\end{array}$ & $\begin{array}{c}11.97 \\
(11.20-12.75)\end{array}$ & $\begin{array}{c}12.27 \\
(11.51-13.03)\end{array}$ & $\begin{array}{c}12.19 \\
(11.41-12.97)\end{array}$ & $-1.943^{* * *}$ & 0.219 & $-1.724^{* * *}$ \\
\hline \multicolumn{9}{|l|}{ Age, years } \\
\hline 16-29 & $\begin{array}{c}13.24 \\
(12.39-14.09)\end{array}$ & $\begin{array}{c}11.93 \\
(11.27-12.59)\end{array}$ & $\begin{array}{c}12.25 \\
(11.73-12.77)\end{array}$ & $\begin{array}{c}10.94 \\
(10.37-11.52)\end{array}$ & $\begin{array}{c}10.51 \\
(9.98-11.04)\end{array}$ & $-0.990^{* *}$ & $-1.739 * * *$ & $-2.729 * * *$ \\
\hline $30-39$ & $\begin{array}{c}17.08 \\
(16.44-17.73)\end{array}$ & $\begin{array}{c}16.05 \\
(15.48-16.63)\end{array}$ & $\begin{array}{c}14.77 \\
(14.23-15.31)\end{array}$ & $\begin{array}{c}14.32 \\
(13.80-14.84)\end{array}$ & $\begin{array}{c}13.97 \\
(13.42-14.52)\end{array}$ & $-2.309 * * *$ & $-0.802 *$ & $-3.110^{* * *}$ \\
\hline $40-49$ & $\begin{array}{c}19.18 \\
(18.45-19.92)\end{array}$ & $\begin{array}{c}17.88 \\
(17.32-18.45)\end{array}$ & $\begin{array}{c}17.38 \\
(16.68-18.09)\end{array}$ & $\begin{array}{c}16.58 \\
(15.98-17.18)\end{array}$ & $\begin{array}{c}16.27 \\
(15.61-16.93)\end{array}$ & $-1.800^{* * *}$ & $-1.117^{* *}$ & $-2.917^{* * *}$ \\
\hline $50-59$ & $\begin{array}{c}18.59 \\
(17.78-19.40)\end{array}$ & $\begin{array}{c}18.75 \\
(18.06-19.44)\end{array}$ & $\begin{array}{c}18.18 \\
(17.40-18.95)\end{array}$ & $\begin{array}{c}17.90 \\
(17.24-18.56)\end{array}$ & $\begin{array}{c}17.88 \\
(17.20-18.56)\end{array}$ & -0.415 & -0.297 & -0.712 \\
\hline $60-69$ & $\begin{array}{c}18.24 \\
(16.88-19.61)\end{array}$ & $\begin{array}{c}16.45 \\
(15.65-17.25)\end{array}$ & $\begin{array}{c}16.99 \\
(16.04-17.95)\end{array}$ & $\begin{array}{c}16.82 \\
(15.99-17.66)\end{array}$ & $\begin{array}{c}16.49 \\
(15.83-17.15)\end{array}$ & -1.254 & -0.503 & $-1.757^{*}$ \\
\hline$\geq 70$ & $\begin{array}{c}13.19 \\
(12.19-14.18)\end{array}$ & $\begin{array}{c}13.39 \\
(12.54-14.23)\end{array}$ & $\begin{array}{c}11.94 \\
(10.98-12.90)\end{array}$ & $\begin{array}{c}12.69 \\
(11.48-13.90)\end{array}$ & $\begin{array}{c}12.93 \\
(12.03-13.83)\end{array}$ & $-1.250 *$ & 0.992 & -0.257 \\
\hline
\end{tabular}

Note: Weighted means and $90 \%$ confidence intervals are reported in the table. T-test was used to compare the change in means. ${ }^{* * *},{ }^{* *}$ and ${ }^{*}$ denote statistical significance at the $1 \%, 5 \%$, and $10 \%$ level, respectively.

We also observed that smokers with primary education or below consumed the most cigarettes on average per day, and their cigarettes consumption per day only decreased by 1.07 from 2010 to 2018. Smokers with higher education consumed fewer cigarettes. Especially for smokers with a college degree or above, their average daily cigarettes smoked were consistently lower than other groups. Table 3 also describes the average consumption of cigarettes per day across age groups. Notably, in most waves, the respondents aged 50-59 had the most average daily consumption of cigarettes, compared to other age groups. It was consistent with the finding in the smoking prevalence. Moreover, smokers aged 30-39 experienced the greatest decrease over time, followed by smokers aged 40-49 and aged 16-29. Yet the reduction in smokers aged 50-59 and those aged over 70 was not statistically significant. The relationship between cigarette consumption per day and age groups was also presented as an inverted U curve for men smokers, as shown in Figure 2. This inverted U pattern was consistent across years. Due to limited observations in each age group in our sample, we did not present the results of average daily cigarettes along with age for women smokers. 


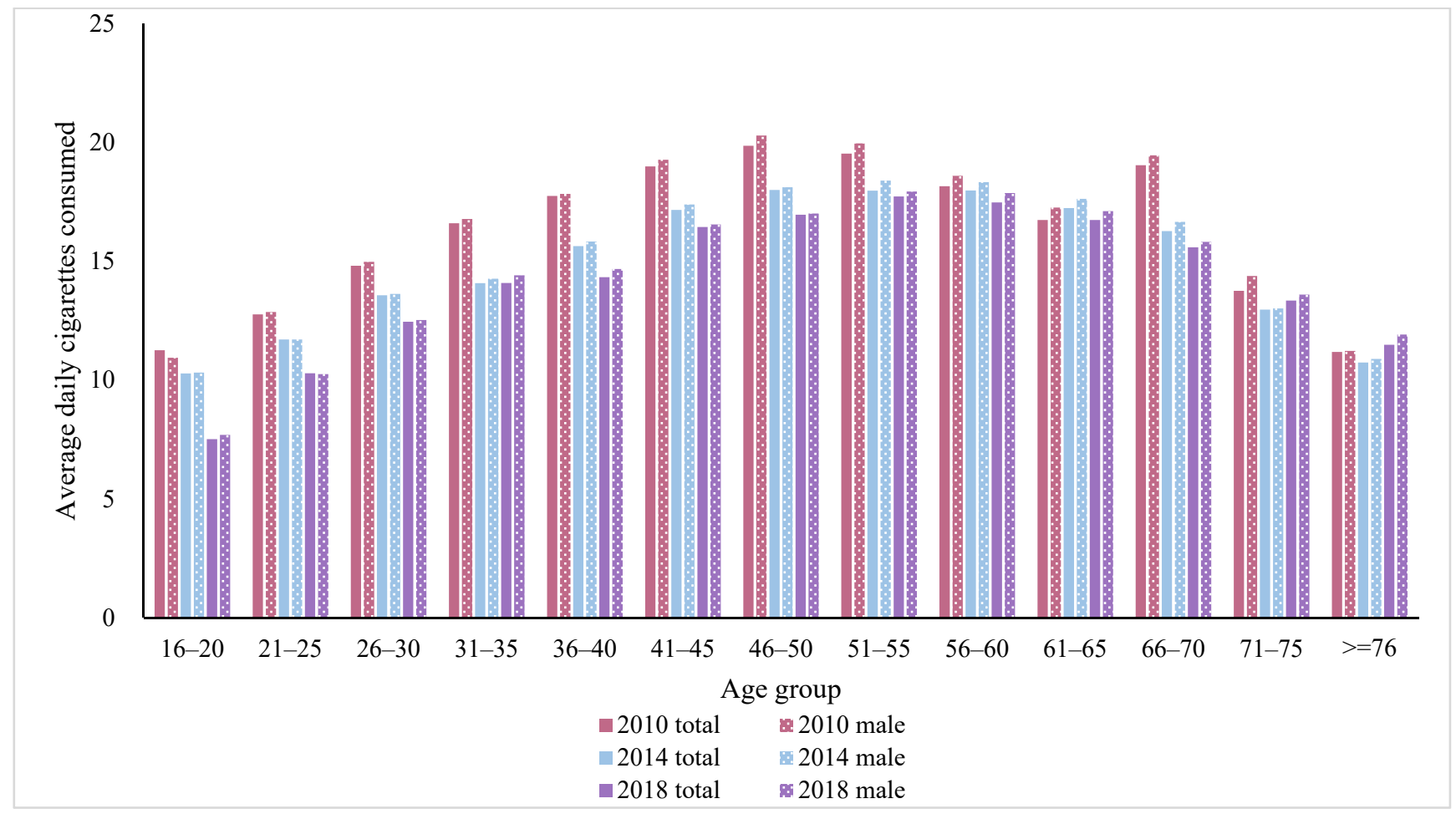

Figure 2. Age-specific trends of number of average cigarettes smoked among smokers in China in 2010, 2014 and 2018. Due to limited observations of women smokers in each age group in our sample, the results for women smokers were not presented.

Table 4 shows the results of gender-stratified regressions on the number of average daily cigarettes using pooled data from five waves. The regressions are based on the ordinary least squares model. For men, a higher education level was associated with less average daily cigarette consumption among smokers. Men having jobs smoked more cigarettes. Current drinkers were positively associated with more average daily cigarettes consumption, compared with non-drinkers. People who did physical activities consumed fewer cigarettes daily. For women, higher education level also mattered for women's daily cigarettes consumption, and it had a greater influence on women than on men. Having jobs or not had limited impacts on women smokers' daily cigarette consumption. Similar to men, women's drinking habits were also associated with increased daily cigarettes consumption, and women smokers who had physical activities consumed fewer daily cigarettes on average.

Table 4. Risk factors associated with number of average daily cigarettes smoked among current smokers.

\begin{tabular}{cccc}
\hline Number of Average Daily & Total & Women & Men \\
\cline { 2 - 4 } Cigarettes & Coef. $\mathbf{( 9 0 \% ~ C I ) ~}$ & Coef. (90\% CI) & Coef. (90\% CI) \\
\hline $\begin{array}{c}\text { Marital status } \\
\text { Unmarried }\end{array}$ & & & \\
Married or cohabited & -0.025 & -1.824 & 0.023 \\
& $(-0.406 \sim 0.356)$ & $(-3.714 \sim 0.066)$ & $(-0.367 \sim 0.412)$ \\
Divorced or widowed & 0.384 & -1.182 & $0.66 *$ \\
& $(-0.142 \sim 0.909)$ & $(-3.188 \sim 0.824)$ & $(0.103 \sim 1.218)$ \\
Educational level & & & \\
Primary or below & $-0.739 * * *$ & $-0.858 *$ & $-0.932 * * *$ \\
Secondary or high school & $(-0.949 \sim-0.530)$ & $(-1.669 \sim-0.0478)$ & $(-1.149 \sim-0.716)$ \\
College or above & $-2.713 * * *$ & -1.69 & $-2.932 * * *$ \\
& $(-3.128 \sim-2.299)$ & $(-3.772 \sim 0.393)$ & $(-3.356 \sim-2.508)$ \\
\hline
\end{tabular}


Table 4. Cont.

\begin{tabular}{cccc}
\hline \multirow{2}{*}{$\begin{array}{c}\text { Number of Average Daily } \\
\text { Cigarettes }\end{array}$} & Total & Women & Men \\
\cline { 2 - 4 } Household income & Coef. (90\% CI) & Coef. (90\% CI) & Coef. (90\% CI) \\
Lower than average & & & \\
Equal to or higher than average & $0.515^{* * *}$ & 0.163 & $0.513^{* * *}$ \\
Work type & $(0.312 \sim 0.718)$ & $(-0.525 \sim 0.851)$ & $(0.302 \sim 0.723)$ \\
Unemployed & & & \\
Self employed & $0.717^{* * *}$ & -0.540 & $0.511^{* * *}$ \\
Employed by others & $(0.442 \sim 0.991)$ & $(-1.323 \sim 0.243)$ & $(0.222 \sim 0.800)$ \\
Current drinker & $0.469 * * *$ & -.385 & 0.135 \\
No & $(0.176 \sim 0.761)$ & $(-1.537 \sim 0.767)$ & $(-0.171 \sim 0.440)$ \\
Yes & & & \\
Physical activity & $2.064^{* * *}$ & $2.854 * * *$ & $1.806 * * *$ \\
No & $(1.866 \sim 2.262)$ & $(1.886 \sim 3.821)$ & $(1.603 \sim 2.010)$ \\
Yes & & & $-1.473 * * *$ \\
Observations & $-1.429 * * *$ & $-0.836^{* *}$ & $(-1.683 \sim-1.263)$ \\
\hline
\end{tabular}

Note: In columns 2 and 3, linear regression models were adjusted for geographical regions, urban/rural status, age and age square, and wave dummies using pooled data from wave of 2010, 2012, 2014, 2016, and 2018. In column 1, the linear regression model further included the gender variable in addition to other control variables. $90 \%$ Confidence intervals for coefficients were reported in the brackets. ${ }^{* *} p<0.01,{ }^{* *} p<0.05,{ }^{*} p<0.1$.

\section{Discussion}

Our study examined the temporal trends in both smoking prevalence and intensity since the Chinese government started to place a greater emphasis on tobacco control. Both encouraging and discouraging findings emerged. Between 2010 and 2018, the overall smoking prevalence in China fell by 1.7 percentage points. This declining trend was consistent with the findings from China Global Adult Tobacco Survey (from $28.1 \%$ in 2010 to $26.6 \%$ in 2018), though it reported a slightly lower smoking prevalence [24,25]. The average daily cigarette consumption decreased by 1.84 as well. Women's smoking prevalence kept much lower. However, it should be noted that the overall smoking prevalence remained high, at $28.69 \%$ in 2018 . Smoking control for men faced a great challenge with its high smoking prevalence of more than 50\%. Furthermore, the smoking prevalence in the young aged 16-20 years increased from $11.72 \%$ in 2010 to $14.29 \%$ in 2018 . If the tobacco control progress continues at the current pace without decisive actions, it may be difficult for the China government to achieve the goal of reducing smoking prevalence to $20 \%$ among people aged 15 and above by 2030, which was set in the Health China 2030 Plan.

The Chinese government can learn from other countries experiences and then take more effective measures to combat the tobacco epidemic, given that many developed and developing countries have seen significant reductions in smoking rates after taking effective measures to discourage tobacco use. In England, the proportion of adults who smoke cigarettes declined from $20.1 \%$ in 2010 to $17.1 \%$ in 2015 [26]. The United States also achieved a dramatic decline in smoking prevalence, dropping from $20.9 \%$ in 2005 to $15.1 \%$ in 2015 [27]. In Thailand, the smoking prevalence among people aged 15 years old or above decreased from $32.0 \%$ in 1991 to $19.1 \%$ in 2017 [28]. In 2014 across Brazil, approximately $15 \%$ of the population were smokers, down from $34.8 \%$ in 1989 [29].

One of the measures to accelerate the progress of tobacco control can be strict regulations on smoking in public places. In recent years, the pace of subnational tobacco control legislation on smoking in public places has accelerated. To date, 107 prefecture-level cities have passed or strengthened regulations on smoking in public places [30]. However, in some of these cities, indoor smoking is not completely prohibited. A more worrisome fact 
is that about two-thirds of Chinese cities have never imposed any regulations on smoking in public places. In light of the difficulty in effectively enforcing smoking bans in some cities, China urgently needs a comprehensive smoking ban legislation the national level.

In addition, China can make warning labels on cigarette packs more prominent. At present, there are only text warnings ("Smoking is harmful to health") on cigarettes package but most cigarettes in China are adorned with beautiful illustrations. Pictorial warnings on packages is proved to be a highly cost-effective and population-wide tobacco control strategy. As of 2014, at least 77 countries or jurisdictions introduced pictures of tobacco-related diseases on cigarette packs, including Canada, Brazil, Singapore, Australia, Thailand, India, and Jamaica [31]. Thailand now has the largest warnings in the world at $85 \%$ of the package front and back, surpassing Australia at 82.5\% [31]. Many initiatives prove that pictorial warnings are better in communicating tobacco-attributed diseases [32], encouraging smoking cessation [33], and discouraging smoking initiation [34], compared to text-only messages. Therefore, pictorial warning images on cigarette packs may be one of the policy options for China's anti-tobacco movement.

Many studies have found solid evidence that increasing the tobacco tax is an effective measure to encourage smoking cessation and reduce smoking intensity [35,36]. In China, taxes on tobacco have been raised twice but the level of taxes is still low. The first tax increase happened in 2009, and the second increase happened in 2015 [8]. However, even after the 2015 tax adjustment, the price of a pack of cigarettes remains relatively low and affordable, with the cost of 12.84 RMB per pack on average in 2015 [37]. In contrast, developed countries imposed much higher tax rates on cigarettes. For example, in 2010, Australia imposed a $25 \%$ excise tax on tobacco without warnings. Then since 2013, a $12.5 \%$ annual increase of excise tax had been implemented [38]. Consequently, Australia now has the world's highest cigarette price and the cost of a pack has risen to \$A40 by 2020 [39]. However, excise taxes in China only account for about 39\% of the final retail price [40], which is still far below the WHO's recommended level of 75\%. Hence, the Chinese government still has much room to further raise cigarettes taxes.

Of particular concern in our results was the substantial increase in smoking prevalence in the young aged 16-20, from $11.72 \%$ in 2010 to $14.29 \%$ in 2018, as shown in Figure 1. Consistently, according to a previous finding, people aged 15-24 experienced the greatest increase in the prevalence of smoking among all age groups [18]. It also showed that 77.9\% of current smokers began smoking during their adolescence [18]. The reason could be that many adolescents and young adults underestimate the health risks of smoking and regard it as a way of socializing. Due to the addictive substances of nicotine, most smokers have great difficulty quitting smoking in later years. Tobacco control initiatives, therefore, need to pay more attention to adolescents and young people. The reality, however, is that although the Law on Protection of Minors in China prohibits the sale of tobacco products to minors and requires identification checks, it is not strictly enforced in practice and adolescents are able to get tobacco products with little difficulty in China. Hence, there is an urgent need in China for an enforceable law to stop adolescents from smoking.

This study also examines the risk factors of smoking behaviors. We found that drinking was strongly associated with the likelihood of smoking in both men and women. Many studies have identified cigarettes and alcohol as complementary products that the utilization of one item may lead to a rise in demand for the other $[41,42]$. The co-use of tobacco and alcohol may further harm the population's health. Lower education is also associated with higher smoking prevalence. Many studies supported that exposure to higher education can improve personal health awareness and promote healthier behaviors $[43,44]$. The phenomenon of higher smoking prevalence in rural areas was perhaps because of lower education levels and less strict anti-smoking interventions. As for the relation between smoking behavior and employment status, gender differences existed. Women with jobs were less likely to smoke perhaps because they might pay more attention to their image since smoking is always considered a masculine behavior in China [45]. By contrast, men having jobs exhibited a higher prevalence of smoking behaviors than those without jobs. As 
is revealed by some public health academics, this could be due to the fact that men smokers can get some social benefits by sharing cigarettes [46]. Moreover, in China, refusing an offered cigarette may also be regarded as rude behavior and may cause exclusion from social groups [47]. Gender differences also existed in the relation between smoking behaviors and marital status. Married men were more likely to be smokers compared to unmarried men, while unmarried women had a higher prevalence of smoking. The difference could be stemmed from that the fact that married women usually take more responsibility for childcare and spend more time with children than married men in China. Considering the harmful impacts of smoking on children's health, married women tend not to smoke.

Our study also has some limitations. First, the latest wave of CFPS surveys was conducted three years ago so we are unable to test trends after 2018. Second, though this study shows a general downward trend, an increased smoking prevalence appears between 2016 and 2018. The reasons for the increase in this period are unclear. Third, this is a cross-sectional study that emphasizes the association between smoking and risk factors. We cannot draw conclusions regarding causality. Fourth, cigarettes smoking is not the only way to use tobacco in China, though the percentage of cigarette smokers among current tobacco smokers reached $96.7 \%$ in 2018 [25]. The consumption of many other tobacco products such as e-cigarettes has been on the rise [48]. Future studies may include the utilization of other tobacco products for analysis when their data is available.

\section{Conclusions}

This study shows declined trends in both smoking prevalence and intensity between 2010 and 2018 in China, suggesting that the Chinese government had made some positive progress in tobacco control over the years. Nevertheless, at the current pace, it may be difficult for China to achieve the goal of reducing the adult smoking prevalence to $20 \%$ by 2030. We recommend that the Chinese government needs to take more effective measures against the tobacco epidemic.

Author Contributions: H.F. conceived the study. G.Z. and J.Z. conducted the data analysis. G.Z. wrote the manuscript. J.Z. and H.F. commented on the revision and approved the final version. All authors have read and agreed to the published version of the manuscript.

Funding: This research is financially supported by Peking University Health Science Center, Grant/Award Number: BMU2021YJ028. The funding source had no involvements in study design; in the collection, analysis and interpretation of data; in the writing of the articles; and in the decision to submit it for publication.

Institutional Review Board Statement: The China Family Panel Study (CFPS) is carried out by the Institute of Social Science Survey, Peking University. It gained an approval from the Institutional Review Board of Peking University (Approval IRB00001052-14010). Because we use second-hand data from the CFPS, the ethics committee of Peking University requires no formal ethics approval for this study.

Informed Consent Statement: All participants were informed about the research questions and study objectives and written informed consents were obtained from all respondents.

Data Availability Statement: The datasets generated and/or analyzed during the current study are publicly available and could be accessible via website: http:/ /www.isss.pku.edu.cn/cfps/ (accessed on 28 November 2021).

Acknowledgments: The authors sincerely thank Haihua Gu for helpful suggestions.

Conflicts of Interest: The authors declare there is no conflict of interest. 


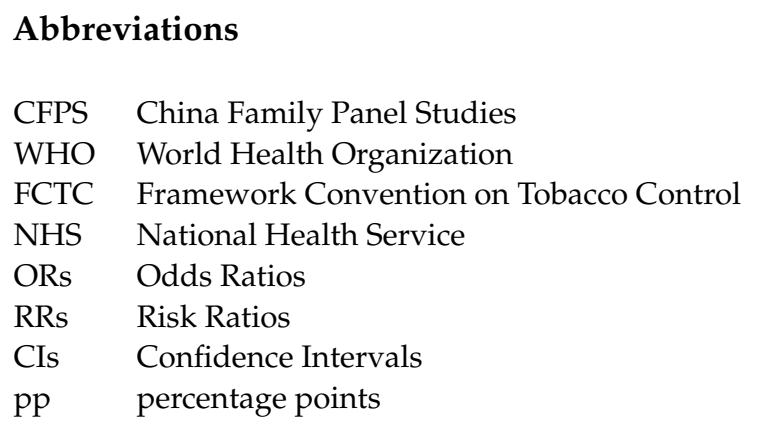

\section{Appendix A}

Table A1. Sample size by subgroups (2010-2018).

\begin{tabular}{|c|c|c|c|c|c|}
\hline & 2010 N (\%) & 2012 N (\%) & 2014 N (\%) & 2016 N (\%) & 2018 N (\%) \\
\hline Individuals & 33,487 & 30,688 & 29,067 & 29,070 & 26,945 \\
\hline \multicolumn{6}{|l|}{ Region } \\
\hline East & $14,413(43 \%)$ & $12,937(42 \%)$ & $12,388(43 \%)$ & $12,097(42 \%)$ & $11,163(42 \%)$ \\
\hline Central & $9882(30 \%)$ & $9124(30 \%)$ & $8681(30 \%)$ & 8457 (29\%) & $7625(28 \%)$ \\
\hline West & $9192(27 \%)$ & $8627(28 \%)$ & $7998(27 \%)$ & $8516(29 \%)$ & 8157 (30\%) \\
\hline \multicolumn{6}{|l|}{ Residence } \\
\hline Rural & $17,946(54 \%)$ & $16,923(55 \%)$ & $15,174(52 \%)$ & $14,904(51 \%)$ & $13,468(50 \%)$ \\
\hline Urban & $15,541(46 \%)$ & $13,765(45 \%)$ & $13,893(48 \%)$ & $14,166(49 \%)$ & $13,477(50 \%)$ \\
\hline \multicolumn{6}{|l|}{ Gender } \\
\hline Female & $17,256(51 \%)$ & $15,618(51 \%)$ & $14,671(50 \%)$ & $14,369(49 \%)$ & $13,332(49 \%)$ \\
\hline Male & $16,231(49 \%)$ & $15,070(49 \%)$ & $14,396(50 \%)$ & $14,701(51 \%)$ & $13,613(51 \%)$ \\
\hline \multicolumn{6}{|l|}{ Education } \\
\hline primary & $16,818(50 \%)$ & $15,857(52 \%)$ & $14,603(50 \%)$ & $13,781(47 \%)$ & $11,846(44 \%)$ \\
\hline middle & $14,373(43 \%)$ & $12,613(41 \%)$ & $12,275(42 \%)$ & $12,449(43 \%)$ & $12,196(45 \%)$ \\
\hline high & $2296(7 \%)$ & $2218(7 \%)$ & $2189(8 \%)$ & $2840(10 \%)$ & 2903 (11\%) \\
\hline \multicolumn{6}{|l|}{ Age, years } \\
\hline $16-29$ & $6535(20 \%)$ & $6138(20 \%)$ & 5539 (19\%) & $5856(20 \%)$ & 4713 (17\%) \\
\hline $30-39$ & $5774(17 \%)$ & $4787(16 \%)$ & 4159 (14\%) & $4271(15 \%)$ & $4040(15 \%)$ \\
\hline $40-49$ & $7739(23 \%)$ & $7170(23 \%)$ & $6492(22 \%)$ & $5848(20 \%)$ & 5045 (19\%) \\
\hline $50-59$ & $6428(19 \%)$ & $5675(18 \%)$ & $5613(19 \%)$ & $5593(19 \%)$ & $5684(21 \%)$ \\
\hline $60-69$ & $4274(13 \%)$ & $4361(14 \%)$ & 4719 (16\%) & $4861(17 \%)$ & 4827 (18\%) \\
\hline$\geq 70$ & $2737(8 \%)$ & $2557(8 \%)$ & $2545(9 \%)$ & $2641(9 \%)$ & $2636(10 \%)$ \\
\hline
\end{tabular}

Table A2. Risk factors associated with current smoking behavior using modified Poisson regression.

\begin{tabular}{cccc}
\hline & Total & Women & Men \\
\hline Current Smoking & $\begin{array}{c}\text { Risk Ratio } \\
\mathbf{( 9 0 \% ~ C I s )}\end{array}$ & $\begin{array}{c}\text { Risk Ratio } \\
\mathbf{( 9 0 \% ~ C I s ) ~}\end{array}$ & $\begin{array}{c}\text { Risk Ratio } \\
\mathbf{( 9 0 \% ~ C I s ) ~}\end{array}$ \\
\hline Marital status & & & \\
Unmarried & $1(\mathrm{ref})$ & $1(\mathrm{ref})$ & $1(\mathrm{ref})$ \\
Married or cohabited & $0.843^{* * *}$ & $0.612^{* * *}$ & $1.219^{* * *}$ \\
Divorced or widowed & $(0.818-0.868)$ & $(0.474-0.791)$ & $(1.189-1.251)$ \\
Educational level & $0.809^{* * *}$ & 0.794 & $1.375^{* * *}$ \\
Primary or below & $(0.777-0.841)$ & $(0.606-1.039)$ & $(1.331-1.420)$ \\
Secondary or high school & $1(\mathrm{ref})$ & $1(\mathrm{ref})$ & $1(\mathrm{ref})$ \\
& $1.140^{* * *}$ & $0.733^{* * *}$ & $0.924^{* * *}$ \\
College or above & $(1.124-1.157)$ & $(0.671-0.800)$ & $(0.913-0.935)$ \\
& $0.868^{* * *}$ & $0.532^{* * *}$ & $0.738^{* * *}$ \\
& $(0.842-0.896)$ & $(0.423-0.670)$ & $(.719-0.757)$ \\
\hline
\end{tabular}


Table A2. Cont.

\begin{tabular}{cccc}
\hline & Total & Women & Men \\
\hline Current Smoking & $\begin{array}{c}\text { Risk Ratio } \\
\mathbf{( 9 0 \% ~ C I s )}\end{array}$ & $\begin{array}{c}\text { Risk Ratio } \\
\mathbf{( 9 0 \% ~ C I s )}\end{array}$ & $\begin{array}{c}\text { Risk Ratio } \\
\mathbf{( 9 0 \% ~ C I s )}\end{array}$ \\
\hline $\begin{array}{c}\text { Household income } \\
\text { Lower than average }\end{array}$ & $1(\mathrm{ref})$ & $1(\mathrm{ref})$ & $1(\mathrm{ref})$ \\
Equal to or higher than average & $0.943^{* * *}$ & $0.674^{* * *}$ & $1.013^{*}$ \\
Work type & $(0.930-0.956)$ & $(0.622-0.731)$ & $(1.001-1.025)$ \\
Unemployed & $1(\mathrm{ref})$ & $1(\mathrm{ref})$ & $1(\mathrm{ref})$ \\
Self employed & $1.442^{* * *}$ & $0.855^{* * *}$ & $1.169^{* * *}$ \\
Employed by others & $(1.415-1.471)$ & $(0.786-0.931)$ & $(1.150-1.189)$ \\
Current drinker & $1.826^{* * *}$ & $0.759^{* * *}$ & $1.262^{* * *}$ \\
No & $(1.790-1.863)$ & $(0.672-0.857)$ & $(1.240-1.284)$ \\
Yes & $1(\mathrm{ref})$ & $1(\mathrm{ref})$ & $1(\mathrm{ref})$ \\
Physical activity & $2.475^{* * *}$ & $3.485^{* * *}$ & $1.255^{* * *}$ \\
No & $(2.445-2.507)$ & $(3.144-3.863)$ & $(1.241-1.268)$ \\
Yes & $1(\mathrm{ref})$ & $1(\mathrm{ref})$ & $1(\mathrm{ref})$ \\
& $0.951^{* * *}$ & 0.955 & $0.905^{* * *}$ \\
& $(0.938-0.965)$ & $(0.887-1.028)$ & $(0.895-0.916)$
\end{tabular}

Note: In column 2 and 3, modified Poisson regression models were adjusted for geographical regions, urban/rural status, age and age square, and wave dummies using the pooled data from waves of 2010, 2012, 2014, 2016 and 2018. In column 1, modified Poisson regression model further included the gender variable in addition to other control variables. $90 \%$ Confidence intervals for Odds Ratio were reported in the brackets. ${ }^{* * *} p<0.01,{ }^{*} p<0.1$.

\section{References}

1. Forouzanfar, M.H.; Afshin, A.; Alexander, L.T.; Anderson, H.R.; Bhutta, Z.A.; Biryukov, S.; Brauer, M.; Burnett, R.; Cercy, K.; Charlson, F.J. Global, regional, and national comparative risk assessment of 79 behavioural, environmental and occupational, and metabolic risks or clusters of risks, 1990-2015: A systematic analysis for the Global Burden of Disease Study 2015. Lancet 2016, 338, 1659-1724. [CrossRef]

2. Yang, G.H.; Li, Q.A.; Wang, C.X.; Hsia, J.; Yang, Y.; Xiao, L.; Yang, J.; Zhao, L.H.; Zhang, J.; Xie, L. Findings from 2010 Global Adult Tobacco Survey: Implementation of MPOWER Policy in China. Biomed. Environ. Sci. 2010, 23, 422-429. [CrossRef]

3. The Political Mapping of China's Tobacco Industry and Anti-Smoking Campaign. Available online: https://www.brookings. edu/wp-content/uploads/2016/06/25-china-tobacco-li.pdf (accessed on 28 November 2021).

4. Statistical Bulletin on National Economic and Social Development in 2010. Available online: http://www.stats.gov.cn/tjsj/tjgb / ndtjgb / qgndtjgb/201102/t20110228_30025.html (accessed on 28 November 2021). (In Chinese)

5. Yang, G.; Kong, L.; Zhao, W.; Wan, X.; Zhai, Y.; Chen, L.C.; Koplan, J.P. Emergence of chronic non-communicable diseases in China. Lancet 2008, 372, 1697-1705. [CrossRef]

6. The Bill China Cannot Afford: Health, Economic and Social Costs of China's Tobacco Epidemic. Available online: https://www.cn.undp.org/content/china/en/home/library/democratic_governance/the-bill-china-cannot-afford--healtheconomic-and-social-costs-o.html (accessed on 28 November 2021).

7. CHINA: 12th Five-Year Plan (2011-2015) for National Economic and Social Development. Available online: http:/ /www.gov.cn/ 2011lh/content_1825838.htm (accessed on 28 November 2021). (In Chinese)

8. Hu, T.W.; Zhang, X.L.; Zheng, R. China has raised the tax on cigarettes: What's next? Tob. Control 2016, 25, 609-611. [CrossRef]

9. Healthy China 2030 Plan Outline. Available online: http:/ /www.gov.cn/zhengce/2016-10/25/content_5124174.htm (accessed on 28 November 2021).

10. Wang, N.; Feng, Y.J.; Bao, H.L.; Cong, S.; Fan, J.; Wang, B.H.; Fang, L.W. Research on smoking situation among Chinese aged over 40 in 2014. Chin. J. Epidemiol. 2018, 39, 551-556. (In Chinese)

11. Chen, Y.Y.; Zhu, L.P.; Yan, W.; Liu, J.; Ji, L.; Xu, Y. Research on current smoking and smoking cessation among adults in Jiangxi in 2013. Chin. J. Epidemiol. 2017, 38, 577-582. (In Chinese)

12. Gao, J.N.; Zheng, P.P.; Gao, J.L.; Chapman, S.; Fu, H. Workplace smoking policies and their association with male employees' smoking behaviours: A cross-sectional survey in one company in China. Tob. Control 2011, 20, 131-136. [CrossRef] [PubMed]

13. Zheng, Y.T.; Ji, Y.; Dong, H.B.; Chang, C. The prevalence of smoking, second-hand smoke exposure, and knowledge of the health hazards of smoking among internal migrants in 12 provinces in China: A cross-sectional analysis. BMC Public Health $2018,18,655$. [CrossRef] [PubMed] 
14. He, H.J.; Pan, L.; Cui, Z.; Sun, J.X.; Yu, C.D.; Cao, Y.J.; Wang, Y.; Shan, G.L. Smoking Prevalence, Patterns, and Cessation Among Adults in Hebei Province, Central China: Implications From China National Health Survey (CNHS). Front Public Health 2020, 8, 177. [CrossRef] [PubMed]

15. WHO Global Report on Trends in Prevalence of Tobacco Use 2000-2025, Fourth Edition. Available online: https:/ /www.who.int/ publications/i/item/9789240039322 (accessed on 28 November 2021).

16. WHO Report on the Global Tobacco Epidemic, 2021: Addressing New and Emerging Products. Available online: https: //www.who.int/publications/i/item/9789240032095 (accessed on 28 November 2021).

17. Qian, J.C.; Cai, M.; Gao, J.; Tang, S.L.; Xu, L.; Critchley, J.A. Trends in smoking and quitting in China from 1993 to 2003 : National Health Service Survey data. B World Health Organ. 2010, 88, 769-776. [CrossRef]

18. Wang, M.H.; Luo, X.; Xu, S.B.; Liu, W.H.; Ding, F.F.; Zhang, X.X.; Wang, L.; Liu, J.; Hu, J.P.; Wang, W. Trends in smoking prevalence and implication for chronic diseases in China: Serial national cross-sectional surveys from 2003 to 2013. Lancet Resp. Med. 2019, 7, 35-45. [CrossRef]

19. Li, S.S.; Meng, L.H.; Chiolero, A.; Ma, C.W.; Xi, B. Trends in smoking prevalence and attributable mortality in China, $1991-2011$. Prev. Med. 2016, 93, 82-87. [CrossRef]

20. Xie, Y.; Hu, J.W. An Introduction to the China Family Panel Studies (CFPS). Chin. Sociol. Rev. 2014, 47, 3-29.

21. Lin, H.X.; Chang, C.; Liu, Z.; Tan, H.Q. The effect of the presence of children on adult smoking behaviour: Empirical evidence based on China family panel studies. BMC Public Health 2020, 20, 1448. [CrossRef] [PubMed]

22. Wang, W.D.; Dong, Y.Q.; Liu, X.H.; Zhang, L.X.; Bai, Y.L.; Hagist, S. The More Educated, the Healthier: Evidence from Rural China. Int. J. Environ. Res. Public Health 2018, 15, 2848. [CrossRef] [PubMed]

23. Li, C.L.; Mao, Z.Z.; He, G.; Hu, Q.T. Does smoking impact trust in physicians and satisfaction with the health system in China? Tob. Induc. Dis. 2021, 19, 6. [CrossRef] [PubMed]

24. Global Adult Tobacco Survey 2010. Available online: https:// extranet.who.int/ncdsmicrodata/index.php/catalog/252/relatedmaterials (accessed on 28 November 2021).

25. Global Adult Tobacco Survey 2018. Available online: https://www.tobaccofreekids.org/assets/global/pdfs/en/GATS_China_ 2018_FactSheet.pdf (accessed on 28 November 2021).

26. Adult Smoking Habits in the UK: 2015. Available online: https://www.ons.gov.uk/peoplepopulationandcommunity/ healthandsocialcare/healthandlifeexpectancies/bulletins/adultsmokinghabitsingreatbritain/2015 (accessed on 28 November 2021).

27. Jamal, A.; King, B.A.; Neff, L.J.; Whitmill, J.; Babb, S.D.; Graffunder, C.M. Current Cigarette Smoking Among Adults-United States, 2005-2015. Mmwr Morbid. Mortal W 2016, 65, 1205-1211. [CrossRef] [PubMed]

28. Intarut, N.; Pukdeesamai, P. The prevalence of secondhand smoke exposure and related factors among schoolchildren in Northeast Thailand. F1000 Res. 2020, 9, 1158. [CrossRef] [PubMed]

29. Cruvinel, E.; Liebman, E.; Leite, I.; Hu, J.X.; Richter, K.P. Prevalence of smoking, quit attempts and access to cessation treatment among adults with mental illness in Brazil: A cross-sectional analysis of a National Health Survey. BMJ Open 2020, 10, e033959. [CrossRef] [PubMed]

30. Qin, Y.Y. Research on Chinese Tobacco Control Regulations. Master's Thesis, Northwest Normal University, Lanzhou, China, May 2021. (In Chinese).

31. Cigarette Package Health Warnings: International Status Report. Available online: http:/ /www.tobaccofreekids.org/content/ press_office/2014/2014_10_14_health_labels.pdf (accessed on 28 November 2021).

32. Thrasher, J.F.; Hammond, D.; Fong, G.T.; Arillo-Santillan, E. Smokers' reactions to cigarette package warnings with graphic imagery and with only text: A comparison between Mexico and Canada. Salud Publica Mexico 2007, 49, S233-S240. [CrossRef]

33. Azagba, S.; Sharaf, M.F. The Effect of Graphic Cigarette Warning Labels on Smoking Behavior: Evidence from the Canadian Experience. Nicotine Tob. Res. 2013, 15, 708-717. [CrossRef] [PubMed]

34. Vardavas, C.I.; Connolly, G.; Karamanolis, K.; Kafatos, A. Adolescents perceived effectiveness of the proposed European graphic tobacco warning labels. Eur. J. Public Health 2009, 19, 212-217. [CrossRef] [PubMed]

35. Marsh, L.; Cameron, C.; Quigg, R.; Hoek, J.; Doscher, C.; McGee, R.; Sullivan, T. The impact of an increase in excise tax on the retail price of tobacco in New Zealand. Tob. Control 2016, 25, 458-463. [CrossRef] [PubMed]

36. Chaloupka, F.L.; Yurekli, A.; Fong, G.T. Tobacco taxes as a tobacco control strategy. Tob. Control 2012, 21, 172-180. [CrossRef] [PubMed]

37. Zheng, R.; Wang, Y.; Hua, X.; Marquez, P.V. Cigarette Affordability in China, 2001-2016; OKR: Washington, DC, USA, 2016.

38. Blakely, T.; Gartner, C. Tobacco taxes have mixed effects on socioeconomic disparities. Lancet Public Health 2019, 4, E595-E596. [CrossRef]

39. Hirono, K.T.; Smith, K.E. Australia's $\$ 40$ per pack cigarette tax plans: The need to consider equity. Tob. Control 2018, 27, 229-233. [CrossRef]

40. Verguet, S.; Tarr, G.; Gauvreau, C.L.; Mishra, S.; Jha, P.; Liu, L.R.; Xiao, Y.; Qiu, Y.P.; Zhao, K. Distributional benefits of tobacco tax and smoke-free workplaces in China: A modeling study. J. Glob. Health 2017, 7, 020701. [CrossRef]

41. Bask, M.; Melkersson, M. Rationally addicted to drinking and smoking? Appl. Econ. 2004, 36, 373-381. [CrossRef]

42. Pierani, P.; Tiezzi, S. Addiction and interaction between alcohol and tobacco consumption. Empir Econ. 2009, 37, 1-23. [CrossRef] 
43. Wang, Q.; Shen, J.J.; Sotero, M.; Li, C.A.; Hou, Z.Y. Income, occupation and education: Are they related to smoking behaviors in China? PLoS ONE 2018, 13, e0192571. [CrossRef]

44. Kvaavik, E.; Rise, J. How Do Impulsivity and Education Relate to Smoking Initiation and Cessation Among Young Adults? J. Stud. Alcohol Drugs 2012, 73, 804-810. [CrossRef] [PubMed]

45. Lee, C.O.; Gao, M.J.; Ryff, C.D. Conscientiousness and Smoking: Do Cultural Context and Gender Matter? Front. Psychol. 2020, 11, 1593. [CrossRef]

46. Pan, Z.F. Socioeconomic predictors of smoking and smoking frequency in urban China: Evidence of smoking as a social function. Health Promot. Int. 2004, 19, 309-315. [CrossRef]

47. Ma, S.J.; Wang, J.F.; Mei, C.Z.; Xu, X.F.; Yang, G.H. Passive smoking in China: Contributing factors and areas for future interventions. Biomed. Environ. Sci. 2007, 20, 420-425. [PubMed]

48. He, G.Y.; Lin, X.S.; Ju, G.D.; Chen, Y.S. Mapping Public Concerns of Electronic Cigarettes in China. J. Psychoact. Drugs 2020, 52, 13-19. [CrossRef] [PubMed] 